\title{
Research on the Cross-border E-Commerce's Influence on the International Market Competitiveness of Chinese Textile Industry
}

\author{
Lei Yao \\ Beijing Institute of Fashion Technology \\ Beijing, China \\ Sxyyl@bift.edu.cn
}

\author{
Si-tong Liu \\ Beijing Institute of Fashion Technology \\ Beijing, China \\ 315562391@qq.com
}

\begin{abstract}
With the stalling performance of the development of Chinese cross-border E-commerce, a number of traditional industries are successively seeking transformation by access to the internet. Textile is one of them. As a kind of new trade mode, the astonishing development of cross-border E-commerce in recent years has undoubtedly provided a clear direction for the development and international market competition of Chinese textile industry. In order to study the cross-border E-commerce's influence on the international competitiveness of Chinese textile, the author of this thesis first discusses the development status quo of Chinese cross-border E-commerce and international textile market. And then, the author conducts research on the cross-border E-commerce's influence on the Chinese textile's competition in the international market. Based on the final analysis, the author provides recommendations for Chinese cross-border E-commerce and textile industry so that crossborder E-commerce can better the development of Chinese textile in the international market. First, we shall provide recommendations over the national policy, second, we shall conduct regulation inside the enterprise. Besides, we shall enhance payment security and improve logistics so that the development of cross-border E-commerce of Chinese textile can be better and better.
\end{abstract}

Keywords-Cross-border E-commerce; Textile; International Market Competitiveness

\section{INTRODUCTION}

Cross-border E-commerce is of utmost strategic significance for pushing forward the economic globalization. Cross-border E-commerce breaks restrictions imposed over nations by time and space. Thus, the cross-border trade that all consumers look forward to gradually is free from national borders and boundaries and economic and trade development of all nations produce significant change. For traditional Chinese enterprises, their means to access to the international market are greatly expanded because of the multilateral economics and win-win trade cooperation formed by the cross-border E-commerce; apart from resources optimization, cooperation and win-win among enterprises have been greatly developed; on the other hand, cross-border E-commerce makes consumers very conveniently get information from other countries and buy cost-effective commodities. It again enables a very great economic development. Chinese traditional textile enterprises shall proactively attempt to use such a technical foundation of cross-border E-commerce. Such move will help intensify supply chain management and control, gradually enhance the brand's international influence and competitiveness in the international market.

\section{CROSS-BORDER E-COMMERCE'S POSITIVE INFLUENCE ON CHINESE TEXTILE'S COMPETITIVENESS IN THE INTERNATIONAL MARKET}

\section{A. Simplify supply chain process, and enhance efficiency of foreign trade of textile}

The appearanceof cross-border E-commerce simplifies the whole supply chain process, and has realized the transformation of the mode from the original suppliermanufacturer-distributor-retailer-user to the current supplier-user. It greatly cuts down cost and enhances profit. Chinese traditional textile export process is very complex. Those export enterprises have to negotiate with foreign buyers and promote their product before enabling sales overseas. It will cost plenty of labor and resources [1]. However, the appearance of cross-border E-commerce has turned such a momentum. Enterprises may directly showcase their own commodities in the cross-border E-commerce internet platform instead of suffering from geological restrictions. The simplification of the whole supply chain greatly enhances the efficiency of foreign trade of Chinese textile.

\section{B. It's favorable for the popularization of textile brand}

Appearance of cross-border E-commerce brings more opportunities for Chinese traditionaltextile enterprises. Refrained by capital and scale, some textile enterprises of small brand don't have the opportunity to make overseas export because the profit earned is not enough to offset cost increase. However, when the cross-border E-commerce has been introduced to the foreign trade, such small traditional textile export enterprises don't need to worry how to make overseas promotion of their product. When their product is posted on the trade platform, people all over the world know their product. Thus, their product begins to reach out to the whole world and be known by more people. Such move is of great help to enhance their brand reputation, which is 
favorable for enhancing the competitiveness of Chinese textile in the international market.

\section{It's favorable for expanding the overseas market of textile}

As of 2016, China has become the world's largest Ecommerce market as well as No.3 cross-border online purchase market. China is undoubtedly the world's crossborder E-commerce market with most vitality and potential. Cross-border electricity trade objects are distributed all over the world. Based on the original development, we shall explore more potential purchase power in such emerging markets as Argentina, Israel, Brazil, the U.S. The conclusion of Free Trade Agreement with Japan and South Korea, covering such contents as E-commerce, environment and cooperation, is favorable for exploring more overseas market. Nowadays, more and more foreign trade enterprises reach out to the overseas market. The China-based cross-border Ecommerce mode targeting the whole world has been gradually set up. Broad market potential and robust demand enable Chinese textile industry to have an unparalleled opportunities and advantages during the cross-border E-commerce contest.

\section{CROSS-BORDER E-COMMERCE'SNEGATIVEINFLUENCE ON CHINESE TEXTILE'S COMPETITIVENESS IN THE INTERNATIONAL MARKET}

\section{A. Intellectual property right's influence on the international reputation of textile}

Cross-border E-commerce based online information is trans-boundary while intellectual property right has the geological characteristics. It's another contradiction arising out of the cross-border E-commerce and intellectual property right. Upon infringement over the intellectual property right, such contradiction makes it difficult to unify the scope governing the dispute, identify the violator or gather evidence for the infringement. [2] It greatly increases the difficulty of processing disputes over the intellectual property right. Besides, technical vulnerabilities arising out of the crossborder E-commerce platform make it possible for vendors without integrity to violate intellectual property right. For example, in the "AliExpress" platform, in spite of stringent management on the usage of brand and name and penalty on violating sellers, some sellers still shun away systemic examination by modifying key words, which increases the difficulty of ruling out the copycat product.

Because of historical and cultural factors, protection on the intellectual property right between China and overseas countries is quite different. Aside from deficiency of independent research and development capabilities, domestic textile enterprises have weak consciousness over intellectual property right protection. Some vendors would like to sell copycat products or faked products for making profits. Some domestic consumers' habits of pursuing cheap commodities also aid the prevalence of copycat products and knockoff. Chinese cross-border E-commerce mainly targets European and American consumers, who have strong protection awareness over the intellectual property right. During the product procurement, consumers would compare product quality and brand reputation. It reflects to a certain extent consumers' emphasis over the ethics and reputation of an enterprise. Therefore, vendors violating overseas intellectual property right will face compensation and disputes. It will affect not only corporate reputation and development, but also international reputation and image of domestic cross-border Ecommerce. It may further affect the competitiveness of Chinese textile product in the international market.

Take China's export to Japan as an example. Although China's total export volume of textile to Japan has been on the rise, its proportion to Chinese total export volume is not so optimistic, and such proportion is on decrease over the years [3]. In 2006, Chinese textile export to Japan accounted for $33.4 \%$ of Chinese total export volume of textile. In 2007-2010, such a proportion was on rapid decrease. The average drop in 4 years was $3.37 \%$. In 2010-2016, China's export volume of textile to Japan was around $20 \%$ of the total export volume of Chinese textile industry: however, in 2013, such a proportion was only $18.71 \%$, roughly half the figure in 2014 , shown in Fig. 2-1.

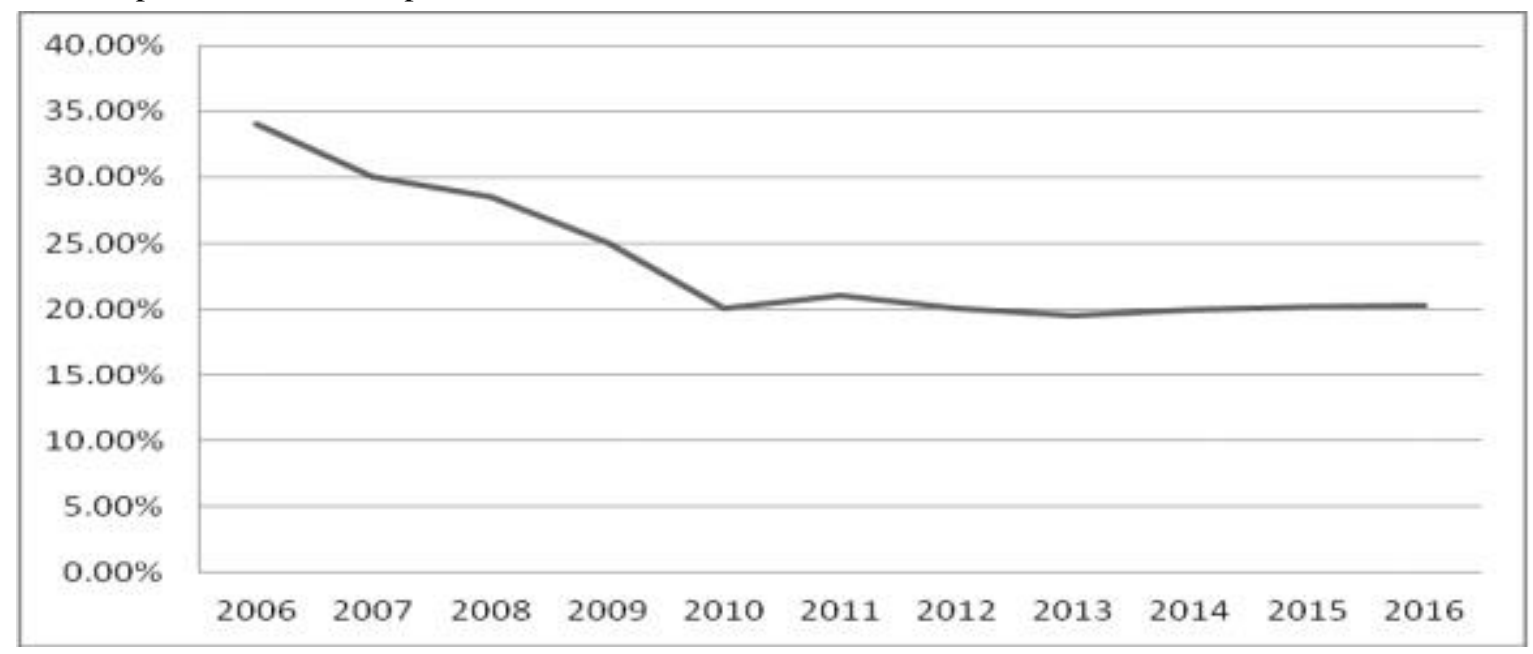

Fig. 1 2006 - 2016Ratio of Aggregate Export Volume of Textile to Japan to Total Export Volume of Chinese Textile 
In Fig. 2-2, Chinese total volume of textile export to Japan has an obvious drop over that in 2006-2014. This stage is called cross-border E-commerce 2.0, with the prevalence of faked product. Many individual sellers use such cross-border E-commerce platform as the Haitao to sell faked products for making more profits. Therefore, it is an era where the grassroot people to make fortunes by internet means. Nowadays, the majority of big E-commerce vendors are evolved from that era, selling faked and copycat products with astonishing profits. Chinese textile export to Japan encountered relatively less trade barriers before 2010. Since 2010, Chinese textile export to Japan has encountered increasing resistance, because
Chinese textile export to Japan was under stringent regulation because of failure to be up to specification. After 2012, Chinese government attached greater importance to textile safety, and tightened supervision and testing. Although trade barrier didn't reduce, batches of product that were under resistance turned better, especially in 2016. It was called the most stringent year of textile safety in history. The State Council passed the revised draft of the Textile Safety Act, which was helpful for enhancing Chinese textile safety and reducing export resistance [4]. In the cross-border Ecommerce 2.0 era, data of Chinese export of textile to Japan that have encountered resistance are given below:

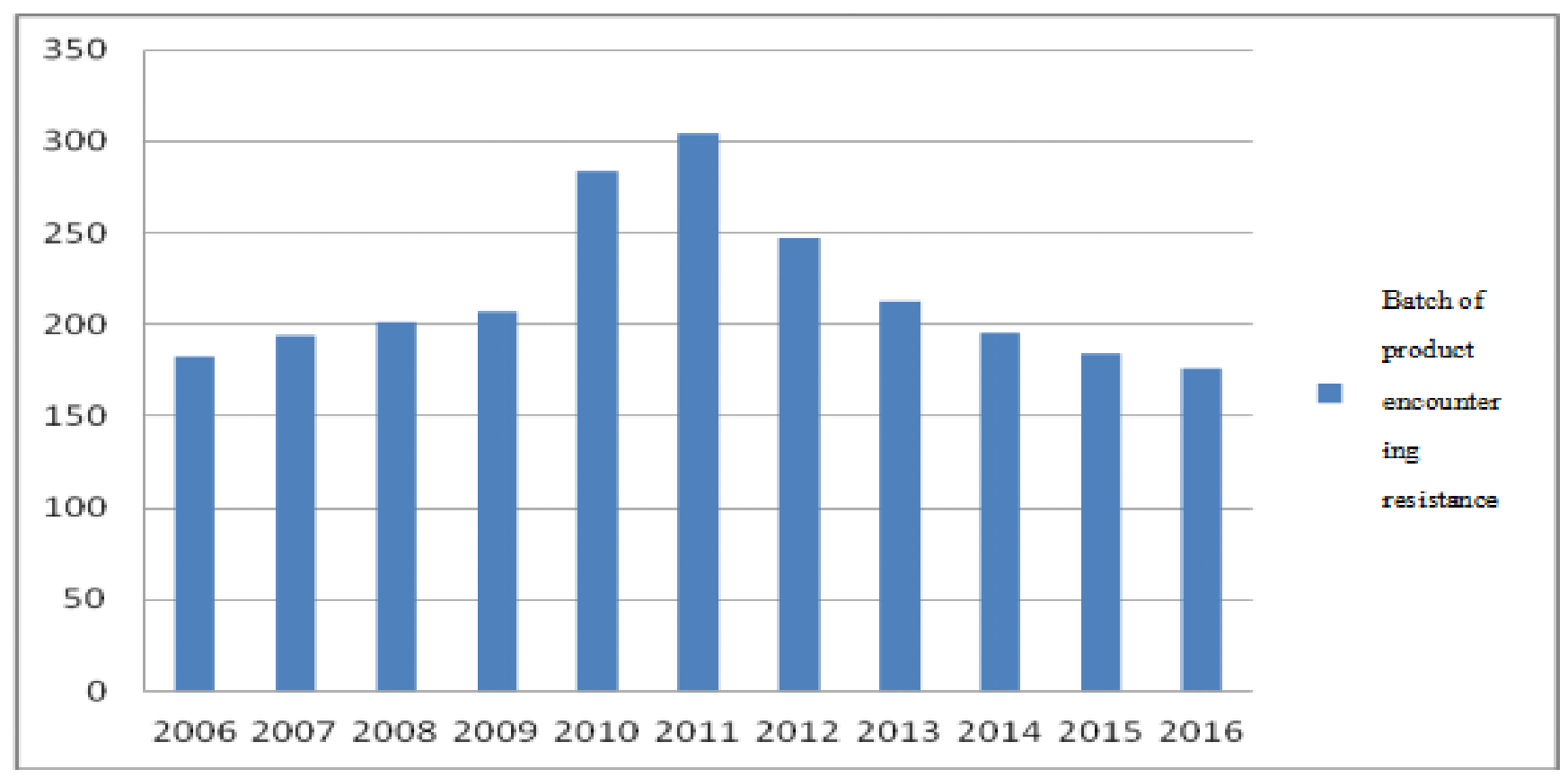

Fig. 2 Batch of Chinese Textile Export to Japan that Encountered Resistance in 2006-2016

\section{B. Frequent problems arising out of the cross-border payment safety leads to decreasing market coverage}

Cross-border payment is a criticallink to realize crossborder E-commerce capital flow. Cross-border E-commerce escrow was in rapid development. Compared with the domestic escrow, it was more complex. The deficiency of a standard and uniform management system of Chinese crossborder payment presents the escrow with many potential risks and problems.

First, payment credit risk: at present, cross-border payment lacks a uniform and all-round credit standard. Besides, the user during registration may use falsified information so that information of the virtual user might not be real. Therefore, it's very difficult for the escrow entity to know the user's credit status. On the other hand, both Parties of cross-border trade may be anonymous. Capital flow under such crossborder trade cannot be reviewed or regulated, and there may be such hazard of group crime. Such problems give users with bad credit the chance to default and fail to keep promise. It
Source of data: arranged by the author based on data in (www.tbt-sps.gov.cn) increases the probability of payment credit risk and affects the sound development of cross-border E-commerce.

Second, payment safety problem: paperless transaction process is one big feature of cross-border E-commerce. The transmission of cross-border payment information tends to be electronic. It enhances the international trade efficiency as well as increases the payment risk. Authenticity of trade information and information of both Parties shall be reviewed. Besides, the complexity of cross-border E-commerce trade process and cross-border trade objects increase the difficulty of determining the identity of payment object and technical risks. In the meantime, hacker and cyber virus attack will lead to information leakage, theft of fund in the virtual account and threat on the user fund safety. Virtual and instant online fund transfer provide opportunity for the circulation of illegal fund. A series of problems have exacerbated the panic of overseas consumers, who dare not purchase textile products online, which is very unfavorable for the competitiveness of Chinese textile industry in the international market. 


\section{Imperfect logistics affects development of market coverage}

For insiders, foreign trade E-commerce is China's only value space that can be tapped. Since 2012, cross-border Ecommerce of foreign trade export has produced a very rapid growth momentum. Business opportunities that produced are infinite.

Rapid development of cross-border E-commerce has produced great impact on the logistics sector. Because of the appearance of plenty of individual online vendors, logistics has been far more crowded than ever. Therefore, inventory digestion has turned into a primary issue. To judge the service quality of one logistics company, you may not necessarily have a full set of solution for the cross-border logistics, because in fact it may be the last straw that crushes a mule. It means that real problems come from the distribution and customer service terminal. For some small cross-border logistics companies, management error may lead to missing packages time and again. It's very time-consuming for crossborder buyers to apply for replacement and rejection and the after-sale service. Because of the high frequency of the missing package by the logistics company, some sellers will feel afraid and they have to deliver package by the registered means. For some overseas storage, if the administrator fails to timely record the logistics information during the transit. It's not convenient for buyers to know their logistics state, and the Customer Service Center has to answer questions in an obscure manner. When the consumer is trying to seek solution in case of logistics problems, some logistics companies will ask the consumer to pay a series of associated expenses to secure their interests so that consumers may have to pay higher and higher expenses. Service quality is severely compromised because of varied cross-border logistics incidents arising out of asymmetric delivery information, seller's wrong processing of postage address and misalignment of warehouse and logistics information. Consumers have lost confidence over the logistics mode of overseas warehouse.

Cross-border E-commerce is indeed hot at present, which cannot hide the problem associated with the whole foreign trade supply chain. Because of the rapid expansion of the cross-border E-commerce scale, the international logistics service cannot fully meet with the seller's order distribution demand. It has covered all deficiencies of the present crossborder logistics provider because restrictions on the development of emerging industries are relaxed. Imperfect logistics service gives bad experience of overseas consumers so that the export competitiveness of Chinese textile industry cannot be increased.

\section{COUNTERMEASURES AND RECOMMENDATIONS}

\section{A. Establish Sound Environment Secured by National Policy}

\section{1) Improve legal system}

First, we shall establish law concerning the intellectual property right protection in the cross-border E-commerce sector so that the intellectual property right may be protected by law. Second, based on labor division and collaboration, we shall clarify responsibilities of law enforcement authority, cope with disputes over intellectual property right strictly abiding by law, intensify law enforcement, increase the cost of violating intellectual property right and ensure stringent law enforcement. Third, we shall strive to maintain the status of Chinese enterprises in the international market, prevent developed countries to boycott Chinese export by excuses of intellectual property right, coordinate protection on the intellectual property right worldwide and proactively formulate and improve international intellectual property right rules, and resolve disputes and safeguard interests pursuant to the international laws and regulations. Finally, we shall intensify publicity and capital input, strive to increase the awareness of the intellectual property right protection of Chinese enterprises and consumers, conscientiously maintain intellectual property right and reduce infringement over the intellectual property right caused by enterprises and individuals.

\section{2) Innovate customs supervision mode}

We shall innovate customs regulation mode, especially policy innovation. We may draw lessons from the practice of Hangzhou, the trial city of Chinese cross-border trade Ecommerce service. Hangzhou has set up national first crossborder trade E-commerce industry park and cross-border Ecommerce clearance service platform- "Kjeport" [2]. The most prominent feature of the platform is to provide rapid clearance and corresponding information enquiry for small cross-border trade enterprises. With respect to the cross-border export, we have set up the business mode of "checklist verification and release and consolidated declaration". It will help resolve problems associated with efficient clearance, standard exchange settlement and tax refund that have bothered small cross-border E-commerce enterprises. In terms of cross-border export, we shall fully support such modes as "direct mail import" and "bonded import". We shall take "rapid clearance and convenient service" as the objective, guide domestic consumers to conduct cross-border online purchase by virtue of "sunshine" channel and secure wholeprocess electronic commodity traceability.

\section{B. Improve Application Inside the Enterprise}

1) Change low price competition and practice brand strategy

At present, the export competitiveness of Chinese textile and clothes relies on to a large extent the lower price. In the long term, the transfer of international industry structure, gradual change of cost structure and domestic economic development will deprive China of its workforce advance and gradually weaken low cost advantages. Therefore, we shall gradually shake off lower price competition mode and find out new competition focus.

In the meantime, although China is the world's biggest supplier of the textile and clothes trade market, there are few self-owned brands. Chinese textile and clothes industry is at the low end of industry chain, and OEM order still accounts for a bigger market proportion. Therefore, Chinese enterprises urgently need to develop self-owned brands and increase the added value of the brand. 


\section{2) Proactively restructure export market}

Currently, Chinese textile and clothes are mainly exported to the U.S., European Union and Japan. Over concentration of export market will increase export risk and competitions among main export nations tend to be fierce.[4] Therefore, we shall sustain the traditional market, continuously development such emerging markets as Southeast Asia, West Asia and Central Asia, etc., increase market diversity, reduce over reliance on the western developed countries and balance the pattern of export market.

\section{3) Speed up Chinese industry structure upgrade}

We shall focus on the current international market demand, increase the textile and clothes export competitiveness and optimize its product structure. The key lies in the technological innovation of the textile and clothes sector. Chinese textile and clothes enterprises shall proactively pay attention to the new technology and equipment concerning the international textile and clothes, intensify technology and research and development input and introduction of advanced technology and equipment. Besides, we shall focus on our own development and secure product diversity, differentiation and profession by technological introduction. In the meantime, we shall attach importance to the development of environment friendly product, alleviate trade barrier and take the corporate social responsibility of promoting social development and environment health.

\section{4) Cultivate and introduce cross-border E-commerce talents}

First, the enterprise shall give full play to the higher education-based cultivation of cross-order E-commerce talents. The enterprise shall increase education input and encourage marketing personnel to conduct further study in the professional school. Such marketing personnel shall learn cross-border E-commerce skills, marketing and sales and management knowledge, keep pace with the times and enrich their own theoretical knowledge and practical capability.

Second, we shall explore the mode of talent cultivation through school-enterprise cooperation. We shall enhance exchanges of outstanding personnel from school and enterprises, combine theory with practice and push forward scientific study on technology, management and marketing in the E-commerce field; we shall regularly invite outstanding corporate professionals to exchange with students and help students to grasp the frontier trend of cross-border Ecommerce; arrange students to conduct internship, let them grasp cross-border E-commerce practice expertise and create more opportunities for students to conduct practice for recovering deficiency of theoretic knowledge. In the meantime, the company shall introduce outstanding talents from school.

\section{Secure Payment Safety}

When the efficient and transparent cross-border shopping channels are established, how to enhance payment safety and establish well-established payment is an important link of the cross-border E-commerce development.

With respect to the online risk arising out of the crossborder payment, we shall enhance security in the cyber technology level. We shall improve technology, reduce the risks of virus attack and phishing, and weaken the hacking possibility. We shall utilize HTMLS technology to reduce webpage jump. We shall enhance collaboration between browser provider and cross-border payment provider, respectively secure website viewing and payment safety. With respect to the payment, we shall transmit data via banking encryption and secure rights and interests of consumers to the maximum extent.

With respect to the credit risk associated with the crossborder payment, we shall improve the payment mode concerning the cross-border E-commerce platform. There are three modes concerning the existing cross-border payment: escrow payment, E-banking payment and Cross-border RMB settlement. When the Measures for the Administration of Trial Launch of Renminbi Settlement of Cross-Border Trade was put in place, cross-border E-commerce payment has become smoother [5]. We shall integrate payment mode of the crossborder E-commerce platform and provide customers with safe and efficient shopping payment experience. We shall join $\mathrm{H}$ payment platform and put in place user real-name system. It will help prevent registration with falsified information and reduce the credit risk of the user. Besides, we shall proactively promote cooperation between the escrow and bank, conduct cross-border E-commerce RMB settlement, enhance supervision on virtual users, enhance supervision on payment based on online name and promote the rapid expansion of the overseas business of the escrow entity. In the meantime, we shall help cross-border E-commerce enterprises to rapidly collect fund, prevent exchange risks and promote sound and rapid development of cross-border E-commerce.

\section{Create an Authentic InternationalLogistics Era}

Alibaba's built "Cainiao Network" and "Big Internet Era" stired a boom in the Chinese E-commerce sector in 2013. In the big logistics era, we shall most efficient distribution of commodities by shaking of the commodities' restrictions imposed by space, time and cost. In the big logistics era, we have the unique solution to such problems as high package cost and slow delivery that have bothered the cross-border Ecommerce, namely to establish the overseas storage warehouse [6]. To set up the overseas warehouse will help resolve the two previous difficult problems. Besides, sellers can remotely manage overseas warehouse. If cargo in the overseas warehouse is updated, they will get feedback in the first place. Besides, it will enable the seller to proactively control the whole logistics process. And again, when the buyer has made purchase online, local delivery will help save time and money. Further enhanced consumer experience will naturally correspond to increase of purchase rate.

However, people usually cannot see the complexity and challenge arising out of the setup of overseas warehouse. Service items covered under the whole solution of crossborder logistics constantly require improvement. Nature and direction of such industry development are consistent with the development tempo of the upstream and downstream of the industry chain. To sum up, a series of service standards formulated by the cross-border logistics company shall be adjusted after sellers and E-commerce platform are accordingly adjusted upon market variation. 
Generally speaking, you shall have your own overseas warehouse storage system, whether it's rented or self-built. We shall overcome a series of problems, including the cost of operation and maintenance, reasonable arrangement of inventory turnover and distribution and after-sale service security. However, these are service risks instead of service incidents. From this point, the value of overseas warehouse in the whole trade chain of cross-border E-commerce not just lies in the reduction of cost, but also enhances the consumer experience. Based on the current logistics chain, to put in place the mode of the distribution of overseas warehouse and bid farewell to the logistics distribution of Chinese traditional enterprises will help the seller make more profit by cutting cost. To simply put, the establishment of overseas warehouse will help the seller to make more profit by cutting cost based on the original logistics mode. Overseas warehouse represents a successful profit-making example in the foreign trade Ecommerce industry structure. It will help make more profit by cost management and improving the whole process.

\section{CONCLUSIONS}

Cross-border E-commerce can better the development of Chinese textile in the international market, but at first we should establish Sound Environment Secured by National Policy and Improve Application Inside the Enterprise. Besides, we shall enhance payment security and improve logistics so that the development of cross-border E-commerce of Chinese textile can be better and better.

\section{ACKNOWLEDGEMENT}

1) Beijing Excellent Talents Cultivating Funding Projects "Research on the optimization path of Beijing garment industry structure under the coordinated development of Beijing Tianjin Hebei" (Fund code: TSJH201510012002).

2) Beijing Excellent Talents Cultivating Funding Projects (Fund Code: 2014000026833ZS06).

3) The key project of social science program for Beijing Municipal Education Commission 2016 (SZ201610011208).

\section{REFERENCE}

[1] LI Jie, Chinese B2C Cross-border E-commerce Market Status Quo and Problem Analysis [J]. Computer Knowledge and Technology, 2015, 29:217-220.

[2] ZHU Kai, Chinese Cross-border E-commerce Development Status Quo Analysis and Relevant Recommendations [J]. Modern Business, 2014, 8: 65-66.

[3] SUN Yanyan, Chinese Cross-border E-commerce Development Status Quo Analysis [J]. Modern Economic Information, 2014, 15:169-170.

[4] MEI Jiangqiao, Chinese Cross-border E-commerce Development Status Quo and Prospect Analysis [J]. Modern Enterprise Education, 2014, 22: 495.

[5] SUN Lei, WANG Fang, Chinese Cross-border E-commerce Development Status Quo and Countermeasures [J]. China Business and Market, 2015, 3:38-41.

[6] Michael E. Porter. Cluster and Economics of Competition. Harvard Business Review [N]. 1998 (11), P12. 